"The impact of labor unions on corporate tax avoidance: evidence from Korea"

\begin{tabular}{|c|c|}
\hline AUTHORS & $\begin{array}{l}\text { Ilhang Shin (Dttps://orcid.org/0000-0003-1221-4519 } \\
\text { Sorah Park (D https://orcid.org/0000-0003-3014-7065 }\end{array}$ \\
\hline ARTICLE INFO & $\begin{array}{l}\text { Ilhang Shin and Sorah Park (2020). The impact of labor unions on corporate tax } \\
\text { avoidance: evidence from Korea. Problems and Perspectives in Management, } \\
\text { 18(2), 114-127. doi:10.21511/ppm.18(2).2020.11 }\end{array}$ \\
\hline DOI & http://dx.doi.org/10.21511/ppm.18(2).2020.11 \\
\hline RELEASED ON & Friday, 15 May 2020 \\
\hline RECEIVED ON & Saturday, 15 February 2020 \\
\hline ACCEPTED ON & Wednesday, 22 April 2020 \\
\hline LICENSE & $\begin{array}{l}(c) \text { EY } \\
\text { This work is licensed under a Creative Commons Attribution } 4.0 \text { International } \\
\text { License }\end{array}$ \\
\hline JOURNAL & "Problems and Perspectives in Management" \\
\hline ISSN PRINT & $1727-7051$ \\
\hline ISSN ONLINE & $1810-5467$ \\
\hline PUBLISHER & LLC "Consulting Publishing Company "Business Perspectives" \\
\hline FOUNDER & LLC "Consulting Publishing Company "Business Perspectives" \\
\hline
\end{tabular}

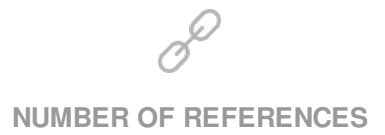

41

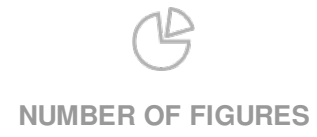

0

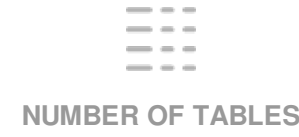

5

(C) The author(s) 2021. This publication is an open access article. 


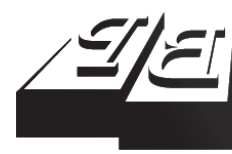

\section{BUSINESS PERSPECTIVES}

LLC "CPC "Business Perspectives" Hryhorii Skovoroda lane, 10, Sumy, 40022, Ukraine www.businessperspectives.org

Received on: $15^{\text {th }}$ of February, 2020 Accepted on: $22^{\text {nd }}$ of April, 2020 Published on: $15^{\text {th }}$ of May, 2020

(C) Ilhang Shin, Sorah Park, 2020

Ilhang Shin, Ph.D., Assistant Professor of Accounting, College of Business, Gachon University, Seongnam-si, Gyunggi-do, South Korea.

Sorah Park, Ph.D., Associate Professor of Accounting, School of Business, Ewha Womans University, Seoul, South Korea. (Corresponding author)

\title{
THE IMPACT OF LABOR UNIONS ON CORPORATE TAX AVOIDANCE: EVIDENCE FROM KOREA
}

\begin{abstract}
This study examines the effect of labor unions on corporate tax avoidance activities. Labor union is an important stakeholder in terms of corporate governance; thus, managers may engage in certain accounting choices that reflect union members' position to improve the relation with labor union. This paper empirically investigates whether managers engage in tax avoidance activities to secure financial resources for workers' pay when the negotiation power of labor unions is higher. The empirical analysis is based on a sample of firms listed in the Korean stock market from 2001 to 2008. The authors find that companies, where labor unions are organized, have a significantly higher level of tax avoidance activities. Also, the authors attempt to examine the effect of labor unions' bargaining power on tax avoidance. While the union membership ratio is not significantly related to tax avoidance, labor unions that belong to upper-level labor organizations significantly affect the increasing tax avoidance activity, on average. Moreover, companies that join an aggressive labor organization ('Minju' Federation) show a significantly higher level of tax avoidance activity, compared to those joining a moderate labor organization ('Hanguk' Federation). Furthermore, the authors show that such an effect of labor unions on tax avoidance is significant for companies, which are not affiliated with large business groups ('chaebols'). This result suggests that chaebol group management is not under pressure to negotiate with union members due to higher reputation costs. The findings of this paper offer academic and practical implications that capital market participants need to understand labor unions' effect on management's accounting choices.
\end{abstract}

\section{Keywords}

JEL Classification

\section{INTRODUCTION}

The main purpose of accounting is to provide useful information for accounting information users' decision making. Accounting information users include a company's stakeholders who are individuals or organizations that are related to a firm's business activities or their outcomes, such as shareholders, creditors, customers, and workers. This study is focused on workers as a company's internal stakeholder and accounting information users in labor-management negotiation. The authors examine the effect of labor unions, specifically the workers' negotiation power, on corporate tax avoidance activities.

Corporate tax avoidance activities are classified into lawful tax reduction to reduce tax burden using the incompleteness of the tax law and tax evasion, which reduces tax cost by violating the tax law. Lawful tax avoidance within a legal boundary is a crucial strategic business activity to reduce the tax burden. Such tax avoidance activities are shown to be related to opportunistic managerial be- 
havior and lower reliability of accounting information. Thus, government regulations and corporate monitoring have been documented to reduce the level of tax avoidance activities (Desai \& Dharmapala, 2005; Wilson, 2009).

The primary purpose of labor unions is to secure or maximize the wage of labor union members. The authors posit that as a labor union's negotiation power increases, managers will be more likely to engage in tax avoidance activities to secure financial resources for workers' pay. The empirical analysis results can be summarized as follows. The association between the firms' unionization and tax avoidance is positive and marginally significant, while the union membership ratio does not significantly affect corporate tax avoidance. Moreover, firms whose labor unions belong to an upper-level labor organization are found to increase their tax avoidance activities, on average. Specifically, companies joining a belligerent upper-level labor organization have significantly higher tax avoidance level than those which joined a moderate upper-level labor organization. These results indicate that managers tend to increase the level of tax avoidance activities to procure financial resources to compensate for workers when the labor unions have higher negotiation power by joining the upper-level labor organizations. Further, additional tests show that the association between labor union and tax avoidance is not significant for firms that are affiliated with large business groups ('chaebols') due to higher reputation costs.

This study makes several contributions to the literature. First, prior studies have focused on firm characteristics and/or corporate governance variables as the factors affecting firms' tax avoidance. Meanwhile, this study provides an important differentiated implication that labor union, key stakeholders of corporations, can affect tax avoidance activities. Second, the research setting based on Korean capital market adds fresh evidence to a stream of research on the relationship between labor union and corporate tax avoidance. Prior research based on U.S. data has relied on industry-level unionization data due to the lack of data availability on firm-level unionization (e.g., Klasa, Maxwell, \& Ortiz-Molina, 2009; Chen, Kacperczyk, \& Ortiz-Molina, 2011). Also, since not all firms disclose their labor-related expenditures, inaccurate sampling may result in a self-selection bias. However, in Korea, companies were required to disclose labor union-related data until 2008. Thus, firm-level unionization data is available for comprehensive coverage of firms in Korea, allowing a more accurate estimation of the relation between labor union and corporate tax avoidance.

The remainder of this paper consists of the following. Section 1 introduces the related literature and sets the research hypotheses. Section 2 describes the sample selection, research model, and empirical methodologies. Section 3 reports the results of empirical analyses, and final section presents the conclusion and its implications.

\section{LITERATURE REVIEW AND DEVELOPMENT OF HYPOTHESES}

\subsection{Labor unions}

U.S. Census Bureau's Annual Survey of Manufacturers (2008) showed that workforce remunerations amounted to USD 784 billion. Compared to the capital expense of USD 166 billion, this reveals the weight of labor expenditure in the manufacturing operation. Managers seek to establish a harmonious working relationship with workers since uncooperative staff could result in unfavorable effects such as slow production, workforce strikes, etc. Unions can change the dynamics between employers and employees since their existence affects incentives and organizational approaches (Banning \& Chiles, 2007). Previous studies have examined the influence of labor unions on various administrative dynamics, for example, CEO compensation (Banning \& Chiles, 2007), leverage (Matsa, 2010), firm performance (Bova, 2013), cost of equity and debt capital (Chen, Kacperczyk, \& Ortiz-Molina, 2011).

Labor unions require management to share information for salary negotiation, although management are inclined to withhold private information 
(Hilary, 2006; Kleiner \& Bouillon, 1988). Since access to essential corporate information could increase the union's bargaining power, managers are more apt to win negotiations with an unapprised workforce by rendering crucial data inaccessible to employees (Croson, 2005). Also, Scott (1994) discovered that Canadian companies, which were prone to strikes, were more likely to downplay detailed information on pension. Moreover, labor union's clamor for salary hikes became more fervent when the labor union showed resilience (Klasa, Maxwell, \& Ortiz-Molina, 2009; Matsa 2010). In fact, as the union's strength increases, the curtailment of information rises (Hilary, 2006).

Labor unions are considered rent-seekers who are motivated to obtain as much quasi-rent as they can through negotiation or strike intimidation (Grout, 1984; Connolly, Hirsch, \& Hirschey, 1986; Hirsch, 1992; Klasa, Maxwell, \& Ortiz-Molina, 2009; Matsa, 2010). Various prior studies have documented that labor unions have significant effects on managers' accounting choice. For instance, managers may maneuver company earnings downward to abate rent pursuit due to labor union pressure (Farber, Hsieh, Jung, \& Yi, 2010). Liberty and Zimmerman (1986) examined the postulation that managers tend to plunge company revenues during a wage negotiation, although they did not find any basis for such a stance before salary bargaining. Succeeding research (Mautz \& Richardson, 1992; Cullinan \& Knoblett, 1994) could not present relevant data showing managerial foresight on earnings before salary talks.

\subsection{Tax avoidance}

Companies create profits through operating activities during the fiscal period, and they have a certain ratio of the created profits to pay to the government as corporate income tax cost. Companies attempt to increase net profit by deducting taxes to pay from gross profits. Concerning this, Dyreng, Hanlon, and Maydew (2008) defined tax avoid- ance as an ability to reduce cash corporate income tax related to profits before taxes. ${ }^{1}$

Because tax cost is an item accompanying cash outflows, reduced tax cost implies a decline in cash outflows. As a firm's cash holdings increase, net profit increases, and the firm can better respond to risks, thereby having a positive effect on firm value. However, if increased cash generated from tax avoidance is not used for stockholders' wealth maximization, thee accompanied cost may be incurred. Due to information asymmetry between the manager and stockholders, a conflict between the stockholders and the manager can become severe. In other words, if the cost related to tax avoidance is greater than the benefit, the negative function of tax avoidance may be exposed.

According to prior studies, corporate governance affects the cost and benefit generated by tax avoidance (Desai, Foley, \& Hines, 2004; Desai \& Dharmapala, 2006). According to agency theory, because a firm's ownership and management are separated, managers may have incentives to take their private benefits, which can be accelerated with information asymmetry between stockholders and managers (Fama, 1980; Fama \& Jensen, 1983). Desai, Foley, and Hines (2004) reported that a firm with good corporate governance (i.e., high transparency) has a lower possibility for a manager to use the profit generated by tax avoidance for his/ her private benefit. Desai and Dharmapala (2006) asserted that managers tend to reduce the level of tax avoidance as executive compensation increases. Therefore, companies with good corporate governance, which is a system that can monitor and oversee the management, can control managers' pursuit of private profit. Consequently, good corporate governance is expected to affect the level of tax avoidance activity.

Many Korean studies also verified the relationship between corporate governance and tax avoidance. Kim, Choi, and Koh (2007) targeted the compa-

1 Tax avoidance is an activity to reduce the tax burden in a method that law does not intend within tax law regulations using the incompleteness of tax laws. Tax evasion is an act to reduce the tax burden in an illegal method, including deliberate distortion of fact; for example, a virtual expenditure stating expenditure that was incurred despite the absence of any real transaction, and over-estimation of expenditure. Tax evasion activity is an act reducing national finances, and other people should pay more tax for tax revenue reduction by tax evasion activity, or a measure to increase the tax rate can be presented. If tax evasion is detected, tax default, and additional tax can be levied and criminal penalty can be imposed. Tax planning is an activity to reduce taxes in a lawful and rational method within a tax law-acknowledged scope, with tax credit or the reduction and exemption of taxes being good examples. Tax avoidance, in a broad sense, can include lawful tax reduction and illegal tax evasion. Tax avoidance, in a narrow sense, can be defined as a tax burden reduction activity, except illegal tax evasion. This study defines tax avoidance activity in a narrow sense. 
nies listed in the Korean stock market and analyzed the characteristics of companies having relevance with tax avoidance tendency. Tax avoidance tendency was significantly related to the tax burden level, profitability, financial cost burden level, and status of the owner's governing company, and it was not significantly related to a company's affiliation with conglomerates. Choi and Suh (2013) also documented a negative relationship between factors such as shareholder rights protection and board of directors, which are the detailed items to evaluate corporate governance, and tax avoidance activity. This implies that tax avoidance activity can be reduced if shareholder rights are well protected, and the responsible action of the board of directors is encouraged. Oh and Kim (2015) analyzed the effects of a firm's ownership structure on tax avoidance based on a sample of listed companies on the Korean stock market from 2002 to 2008 . They found a significantly positive relationship between the largest stockholder's equity ratio and tax avoidance in the $0-20 \%$ and $20-50 \%$ range of the largest stockholder's equity ratio sections. Also, they documented a significantly negative relationship between foreigners' equity ratio and tax avoidance.

While many studies have focused on firm-level characteristics affecting tax avoidance, there is sparse evidence on the role of labor union, another key stakeholder of a company, in tax avoidance. Hence, this study is differentiated from prior studies by identifying the effect of a labor union's negotiation power on tax avoidance.

\subsection{Hypotheses development}

Interest in the status of a company having a labor union, namely the classification of companies having labor unions and those without labor unions, is a study field that has been dealt with heavily in the theory of labor relations. The reason is that studies on the determinants of joining labor unions empirically show the differences between companies having labor unions and those without labor unions.

The primary goal of the labor union is to maximize union members' compensation; thus, managers of the companies having labor unions are likely to experience pressure on wage raise, com- pared to the companies not having labor unions. In a situation where labor unions, claimants of residual income, exist, more incentives for managers to procure financial resources exist through managers' tax avoidance activity. According to inference on prior studies, managers in the case of labor union existence are predicted to enhance incentives to procure financial resources through tax avoidance activity, which is an opportunistic purpose to respond to a labor union's demand for wage raise, and thus hypotheses are set as follows:

H1: There is a positive association between unionization and tax avoidance activities.

A labor union's negotiation power can be measured in two ways. First, a labor union's negotiation power can be measured with union ratio according to prior studies. Union ratio is the value in which the number of labor union members is divided by the total number of employees (Clark, 1984; Hirsch \& Link, 1987; Bronars \& Deere, 1991; Bronars \& Deere, 1993; Klasa, Maxwell, \& OrtizMolina, 2009; Matsa, 2010). In other words, it is based on a hypothesis that a labor union's negotiation power is consolidated as a labor union's union ratio becomes higher.

Another value to measure in relation to a labor union's negotiation power is whether a company has joined an upper-level labor organization. In case a company's labor union has joined an upper-level labor organization, the labor union's negotiation power can be higher than that of the companies where labor unions have not joined an upper-level labor organization because an upper-level labor organization supports its member company's collective bargaining process, and there is a possibility to hugely contribute to the maximization of a member company's labor union member's compensation through strikes using the organization's member companies.

In a real-life scenario, the status of joining an upper-level labor organization can show the company's negotiation power compared to union ratio. Also, the company's manager tries to cope with the upper-level labor organization's strikes by paying more attention to whether its labor union has joined an upper-level labor organization. As a labor union's negotiation power strengthens, man- 
agers will be more interested in procuring financial resources for workers' compensation. Since the status of joining an upper-level labor organization can show a company's negotiation power, those companies whose labor unions joined the upper-level labor organization will receive direct wage raise pressure compared to the companies whose union rate at the individual company level is high. Therefore, in situations where the labor union, a claimant of the residual income, exists, the incentives for managers to procure financial resources through tax avoidance becomes bigger.

As such, the membership to upper level labor organizations is forecast to increase the incentives to procure financial resources through tax avoidance, compared to union ratio; thus, the following hypothesis is set.

H2: The status of membership to an upper-level labor organization will have a bigger effect on a firm's tax avoidance, compared to union ratio.

The majority of the unions in Korea are part of the Minju or Hanguk alliance. In a 2008 Labor White Paper article, it was found that there were 5,889 unionized companies, consisting of 1,559,172 members, with 3,429 affiliated to the Hanguk group (755,234 delegates) and 1,143 to the Minju group (627,274 delegates). The rest of the 1,317 companies with 176,671 members were not affiliated to any group. This means that approximately 89 percent of unionized workers are linked to one of the two chief groups, with Hanguk taking the higher percentage. The two groups have significantly distinct backgrounds, philosophies, and inclinations. They demonstrate dissimilar approaches in handling salary discussions and government-set labor programs (Yoon \& Lee, 2008).

Hanguk, which was founded in 1954, was partial to government programs and was the sole legal union group until 1996. As it followed government-set policies under the country's authoritarian rule, it created agendas that were judicious and forthcoming for managers (Labor Institute Korea 2003). Minju, on the other hand, was a union-formed group created in 1990. Its founders differed from Hanguk's leaders based on the latter's government-based stance. Minju became an official group in 1996 de- spite five years of government repression. Due to these diverging contexts, these two clusters engaged in distinct practices. As commonly publicized in Korean broadcasts, Minju has been belligerent and hostile towards government programs. The Labor White Paper states that 87.2 percent or 565 cases of 648 strikes transpired because of Minju, whereas Hanguk started only 11.4 percent or 83 cases within 2005-2008. This indicates that Minju is inclined to take a pro-active posture and is not hesitant to stage strikes if its claims are not addressed. Meanwhile, Hanguk is predisposed to take a moderate standpoint and is more willing to settle with management.

The total of non-aligned unions has been on a constant rise since the year 2000. Some labor groups have been disgruntled with the policies of major coalitions and have thus stopped associating with them altogether. These non-aligned parties are more drawn to everyday matters instead of political topics, choosing more neutral resolutions over stringent measures such as a labor strike. A board study of the Korean Labor Institute in 2008 revealed that the weekly working hours bargained by Minju averaged 47.6 hours, Hanguk 48.7 hours, and non-aligned groups 59.6 hours. The typical number of negotiation discussions also varied across union alliances, measuring 7.94, 6.12, and 5.03 for Minju, Hanguk, and non-aligned unions, respectively. Minju records the highest difference between wage increase demands and the rate provided by management during negotiation, with 5.0 percent for Minju, 4.6 percent for Hanguk, and 2.7 percent for non-aligned groups. This demonstrates Minju's uncompromising position.

H3: Companies that joined a belligerent upper-level labor organization (Minju Federation) will have a bigger impact on a manager's tax avoidance activity, compared to membership to moderate upper-level labor organization (Hanguk Federation).

\section{METHODS}

\subsection{Measures related to labor unions}

As for the data on the current status of companies' labor unions, they are an item to be disclosed for business reports, and the information 
included in the current status of labor unions can be: member, number of members, number of full-time workers, and affiliated federation. Whether companies have labor unions or not, union ratio measurement by the company is possible. This study collected data on the number of union members to identify the status of labor unions and union ratio according to the study's purpose.

The variables used to measure the effect of labor unions are as follows: First, the status of having a labor union (UNION) is a dummy variable having 1 point if the union member is 1 or more, or 0 otherwise. Second, the intensity of labor unions was measured by union ratio according to prior studies. Union ratio is the value calculated by dividing the number of labor union members by the total number of employees (Clark, 1984; Hirsch \& Link, 1987; Bronars \& Deere, 1991; Bronars \& Deere, 1993; Klasa, Maxwell, \& Ortiz-Molina, 2009; Matsa, 2010).

Because the data on labor union by the company can be acquired from the business report in Korea, an econometric control method can be adopted in consideration of an endogeneity problem. There is an advantage that hypothesis verification is possible based on more sophisticated analysis in that it is free from the measurable error problem that occurs when industry-level data are used.

\subsection{Measures of tax avoidance}

It is difficult to measure tax avoidance activity because a firm's tax return data are not disclosed. Therefore, studies to address such a problem continue to be carried out (Manzon \& Plesko, 2001; Desai \& Dharmapala, 2006; Dyreng, Hanlon, \& Maydew, 2008). In this study, the method to measure tax avoidance presented by Desai and Dharmapala (2006) is used. Desai and Dharmapala (2006) assert that a firm's tax avoidance is included in the part where the difference between profit from financial report and profit from tax report cannot be explained with a profit-adjusting act. Consequently, the value to measure the following tax avoidance activity is developed. A firm's tax avoidance activity is measured using the same method in this study. Its profit from tax report is measured by dividing corporate income tax on the financial statement by a firm's highest corporate income tax rate (Manzon \& Plesko, 2001). Subsequently, the difference between the profit from financial report (net profit before corporate income tax) and estimated profit from tax report is calculated. The companies whose profit from tax report is calculated as 0 or negative (-) in value has small incentives to conduct tax avoidance; thus, this study measures tax avoidance activity by being composed only of the companies with more than 0 profit from tax reports.

As stated above, because a firm's tax avoidance activity is included in the part where the difference between the profit from financial report and profit from tax report cannot be explained with profit-adjusting activity, the tax avoidance measured value can be calculated only if the part generated by profit adjustment for financial report purpose in the BTD generation factors is removed. Desai and Dharmapala (2006) measure a manager's profit-adjusting activity level using total accruals. As an alternative value of profit-adjusting activity, this study reported no difference in the result, although discretionary accruals are used.

By referring to the above, this study conducts a regression analysis by year and by industry using the following equation, Equation (1), by using discretionary accruals that can be viewed as more accurate than the alternative value of profit adjustment. This study then views the drawn residual as TA1 and the total accruals as an alternative value of profit adjustment, carrying out a regression analysis by year and by industry using the Equation (1) model and defining the drawn residual as TA2.

$$
B T D=\beta_{1} D A(T O T A L A C C)+\varepsilon,
$$

where BTD - difference between the accounting profit and profit from tax report, divided by beginning assets, $D A$ - discretionary accruals/beginning assets, TOTALACC - total accruals/beginning assets, $\varepsilon$ - residual [TA1 (TA2) - tax avoidance measure].

\subsection{Model specifications}

The following model (2) is used to test our research hypothesis: 


$$
\begin{aligned}
& \text { TA1 }(\text { TA2 })=\beta_{0}+\beta_{1} \text { UNION }+ \\
& +\beta_{2} \text { SIZE }+\beta_{3} \text { LEVERAGE }+ \\
& +\beta_{4} R O A+\beta_{5} I N V E S T+\beta_{6} D A+ \\
& +\beta_{7} O C F+\beta_{8} G R W A+\beta_{9} G R W L+ \\
& +\beta_{10} F O+\beta_{11} \text { BIG }+ \\
& +\sum Y R+\sum I N D+\varepsilon
\end{aligned}
$$

where $T A$ - tax avoidance measures based on equation (1), UNION - a dummy variable, which equals 1 if a firm is unionized, and 0 otherwise, SIZE - the logarithm of total assets, LEVERAGE total liabilities divided by total assets, INVEST (changes in tangible assets excluding land + Depreciation $+\mathrm{R} \& \mathrm{D}$ expenses)/beginning assets, $D A$ - discretionary accruals (Kothari, 2005), $O C F$ - (cash and cash equivalents + short-term investments)/total assets, GRWA - growth rate of total assets, GRWL - growth rate of total liabilities, $F O R$ - proportion of ownership held by foreign investors, $B I G$ - proportion of ownership held by the largest shareholders (including family members and other related parties), $Y R$ - year indicators, $I N D$ - industry indicators.

The method to measure as presented by Desai and Dharmapala (2006) was used for the value of tax avoidance, which is a dependent variable in Equation (4). The variable of interest in the equation is competition level. This study aims to verify the relationship between the goods market competition level and tax avoidance activity. If tax avoidance activity is reduced, the regression sign is predicted to have a negative value as competition in the goods market increases.

In addition to the competition in the goods market, a variable of interest, this study referred to prior studies to control the factors that can affect tax avoidance activity, and included various control variables in the analysis model. To control a firm's size difference, this study included a firm's size variable as measured by taking the natural logarithm in the total basic assets as a control variable. Because the tax reduction effect of firms with high liabilities is relatively higher due to liabilities, a tax avoidance reduction possibility exists as a non-liability means to reduce tax (DeAngelo \& Masulis, 1980; Schallheim \& Wells, 2004; Jeon, 2004; Graham \& Tucker, 2006), and liabilities ratio (leverage: $L E V)$ was included. As profit level becomes higher, there are incentives to reduce tax burden in the taxation period concerned, and this study selected the return on assets $(R O A)$, indicating profitability as a control variable to regulate an individual company's profit level. Because the Korean tax law awards tax benefits to investments in assets targeted for depreciation and investment in $\mathrm{R} \& \mathrm{D}$, tax savings amount is forecast to be bigger as investment level gets higher. Therefore, this study included investment level (INVEST) in the study model. DA was also included as a control variable to control the effect of a firm's profit adjustment on tax avoidance. Since firms lacking cash have the potential to be more prone to tax avoidance, this study used a cash holding variable to control it (Park, Lee, \& Hong, 2009). According to Kim and Jeong (2006), a firm's profit adjustment affects the total assets change rate and total debt change rate, as well as asset and debt sizes. The relationship between total asset change rate and tax avoidance can differ according to political cost theory or political power theory hypotheses equivalent to asset size. Although firms, whose debts increased, showed lower tax avoidance level due to the reduction of profit from the tax report due to a debt's tax reduction effect, the firms whose debts fell could not use a debt's tax reduction effect, and thus they tried to reduce profit from tax report by increasing tax avoidance level. Therefore, debt change rate presents a possibility of creating a negative relationship with tax avoidance. As a proportion of ownership held by foreign investors (FOR) is higher, tax avoidance activity monitoring consolidation is likely to be higher, and thus the FOR variable was added as a control variable (Park, Lee, \& Hong, 2009). As the proportion of ownership held by the largest shareholder $(B I G)$ gets higher, the firm will prefer cash secured through tax avoidance; thus, the variable $B I G$ was added as a control variable. Lastly, the industry dummy $(I N D)$ and year dummy $(Y D)$ variables were included in the model to control the differences by year and by industry under tax law regulations (Kim \& Jeong, 2006). We also adjusted standard error for firm clusters (Petersen, 2009). 


\subsection{Sample selection procedure}

The analysis subject of this study was the firms listed in the Korean stock market from 2001 to 2008. The financial statement and stock price data used in this study were extracted from the KIS-VALUE database. Firms belonging to financial industries and those with non-December year-end were excluded from the sample due to difficulty in comparing financial statements. Also, companies with impaired capital were excluded from the study since these observations may distort the forecast. After we removed observations with insufficient financial data, the final sample consisted of 3,605 firm-year observations.

\section{EMPIRICAL RESULTS}

\subsection{Descriptive statistics}

Table 1 presents the summary statistics of test variables used in the empirical analyses. The mean value of UNION is 0.6521 , indicating that $65 \%$ of our sample firms are unionized. $46 \%$ of unionized firms are affiliated with upper-level labor organizations: $17 \%$ with Minju Federation and 29\% with Hanguk Federation. The average sample firm has logged total assets of 18.48 , liabilities to assets ratio of 0.44 , ROA of 0.04 , foreign ownership of $11 \%$, and largest shareholders' ownership of 35\%.
Also, Table 1 reports the Pearson correlation coefficients among test variables. Correlations analysis suggests that unionized firms are likely to have larger total assets, higher liabilities to assets ratio, greater investments, higher ownership of foreign investors, and largest shareholders.

\subsection{H1: Unionization and tax avoidance}

Table 2 provides the regression test results of $H 1$, which examines the association between firms' unionization and tax avoidance level.

In Panel $\mathrm{A}$, the dependent variable is $T A 1$, which is the tax avoidance measure using total accruals as the proxy of earnings manipulation. The regression coefficient of UNION is 0.0045 ( $p$-value $=$ 0.0866 ), positive and significant at $10 \%$ level. Panel $\mathrm{B}$, in which the dependent variable is TA2 using discretionary accruals to proxy earnings manipulation, shows that the key variable UNION has a positive coefficient of 0.0041, with $p$-value $=0.1090$. These results indicate that unionized firms tend to have greater corporate tax avoidance activity.

Regarding control variables, corporate tax avoidance is positively associated with firm size, leverage, ROA, cash holdings, and assets growth. However, investments, prior-year discretionary accruals, liabilities growth, and foreign investors' ownership are negatively related to tax avoidance.

Table 1. Descriptive statistics and correlations

\begin{tabular}{|c|c|c|c|c|c|c|c|c|c|c|c|c|c|c|}
\hline No. & Variable & Mean & S.D. & 3 & 4 & 5 & 6 & 7 & 8 & 9 & 10 & 11 & 12 & 13 \\
\hline 1 & UNION $_{\text {it }}$ & 0.65 & 0.48 & - & - & - & $0.17^{* *}$ & $0.08^{* *}$ & -0.01 & $-0.04 *$ & 0.02 & 0.02 & $0.1^{* *}$ & $0.05^{* *}$ \\
\hline 2 & UNION_REGI & 0.46 & 0.23 & $0.11^{* *}$ & $0.04^{*}$ & $0.08^{* *}$ & -0.03 & 0.03 & -0.04 & $-0.05^{*}$ & $-0.06^{* *}$ & $0.06^{* *}$ & -0.03 & 0.04 \\
\hline 3 & UNION_FED & 0.46 & 0.50 & - & $0.48^{* *}$ & $0.7^{* *}$ & $0.26^{* *}$ & $0.06^{* *}$ & $0.1^{* *}$ & $0.05^{*}$ & 0.02 & 0.03 & $0.14^{* *}$ & 0.02 \\
\hline 4 & UNION_MINJU ${ }_{i t}$ & 0.17 & 0.37 & - & - & $-0.29 * *$ & $0.18^{* *}$ & $0.14^{* *}$ & 0.02 & 0.03 & 0.03 & -0.01 & $0.09 * *$ & -0.00 \\
\hline 5 & UNION_HANGUK & 0.30 & 0.46 & - & - & - & $0.14^{* *}$ & $-0.05^{*}$ & $0.09 * *$ & 0.02 & 0.00 & $0.04^{*}$ & $0.07^{* *}$ & 0.02 \\
\hline 6 & $\mathrm{SIZE}_{\mathrm{it}}$ & 18.49 & 1.73 & - & - & - & - & 0.01 & $0.29^{* *}$ & $0.16^{* *}$ & $-0.05^{* *}$ & $0.28 * *$ & $0.6 * *$ & $-0.10^{* *}$ \\
\hline 7 & LEVERAGE $_{\text {it }}$ & 0.45 & 0.19 & - & - & - & - & - & $-0.34^{* *}$ & $0.04 *$ & $-0.08^{* *}$ & $-0.17^{* *}$ & $-0.09 * *$ & $-0.08^{* *}$ \\
\hline 8 & $\mathrm{ROA}_{\mathrm{it}}$ & 0.05 & 0.07 & - & - & - & - & - & - & $0.20 * *$ & $0.33^{* *}$ & $0.47^{* *}$ & $0.27^{* *}$ & 0.03 \\
\hline 9 & INVEST $_{\text {it }}$ & 0.02 & 0.05 & - & - & - & - & - & - & - & 0.02 & $0.17^{* *}$ & $0.09 * *$ & $0.03^{*}$ \\
\hline 10 & $\mathrm{DA}_{\mathrm{it}}$ & 0.01 & 0.09 & - & - & - & - & - & - & - & - & $-0.53^{* *}$ & $-0.05^{* *}$ & $0.05^{* *}$ \\
\hline 11 & $\mathrm{OCF}_{\text {it }}$ & 0.07 & 0.09 & - & - & - & - & - & - & - & - & - & $0.27^{* *}$ & -0.03 \\
\hline 12 & $\mathrm{FOR}_{\mathrm{it}}$ & 0.11 & 0.15 & - & - & - & - & - & - & - & - & - & $0.34^{*}$ & $-0.11^{* *}$ \\
\hline 13 & $B I G_{i t}$ & 0.36 & 0.19 & - & - & - & - & - & - & - & - & - & - & 1.00 \\
\hline
\end{tabular}

Note: ${ }^{*} p<0.05,{ }^{* *} p<0.01$. 
Table 2. Unionization and tax avoidance activities

\begin{tabular}{|c|c|c|c|c|}
\hline \multirow{2}{*}{ Variable } & \multicolumn{2}{|c|}{$\begin{array}{c}\text { Panel A: } \\
\text { Dependent variable }=T A 1\end{array}$} & \multicolumn{2}{|c|}{$\begin{array}{c}\text { Panel B: } \\
\text { Dependent variable }=T A 2\end{array}$} \\
\hline & Coefficient & $p$-value & Coefficient & $p$-value \\
\hline Intercept & -0.0581 & $<0.01$ & -0.0530 & $<0.01$ \\
\hline UNION $_{\text {it }}$ & 0.0045 & 0.0866 & 0.0041 & 0.1090 \\
\hline $\mathrm{SIZE}_{i \mathrm{t}}$ & 0.0018 & 0.0985 & 0.0017 & 0.0947 \\
\hline LEVERAGE $_{\text {it }}$ & 0.0218 & $<0.01$ & 0.0198 & $<0.01$ \\
\hline $\mathrm{ROA}_{\mathrm{it}}$ & 0.2885 & $<0.01$ & 0.2035 & $<0.01$ \\
\hline INVEST $_{\text {it }}$ & -0.1242 & $<0.01$ & -0.1208 & $<0.01$ \\
\hline $\mathrm{DA}_{\mathrm{it}-1}$ & -0.0768 & 0.0233 & 0.0361 & 0.2620 \\
\hline $\mathrm{OCF}_{i t}$ & 0.0774 & 0.0193 & 0.1383 & $<0.01$ \\
\hline GRWA $_{\text {it }}$ & 0.1348 & $<0.01$ & 0.1310 & $<0.01$ \\
\hline $\mathrm{GRWL}_{\text {it }}$ & -0.0489 & $<0.01$ & -0.0463 & $<0.01$ \\
\hline $\mathrm{FOR}_{\mathrm{it}}$ & -0.0293 & 0.0121 & -0.0296 & $<0.01$ \\
\hline $\mathrm{BIG}_{\text {it }}$ & 0.0056 & 0.3880 & 0.0050 & 0.4242 \\
\hline Industry fixed effect & \multicolumn{2}{|c|}{ YES } & \multicolumn{2}{|c|}{ YES } \\
\hline Year fixed effect & \multicolumn{2}{|c|}{ YES } & \multicolumn{2}{|c|}{ YES } \\
\hline Firm clustering & \multicolumn{2}{|c|}{ YES } & \multicolumn{2}{|c|}{ YES } \\
\hline Adj. $R^{2}$ & \multicolumn{2}{|c|}{0.2776} & \multicolumn{2}{|c|}{0.2597} \\
\hline$N$ & \multicolumn{2}{|c|}{3,605} & \multicolumn{2}{|c|}{3,605} \\
\hline
\end{tabular}

\subsection{H2: Unions' negotiation power and tax avoidance}

Table 3 reports the test results regarding the relationship between the bargaining power of labor union and tax avoidance. Panel A and Panel B report the firm-level and industry-level test results, respectively. Although the regression coefficient of UNION_REGI is not statistically significant in Panel A, the coefficient of UNION_FED is positive and significant at $10 \%$ level $(0.0055, p$-value $=0.0560 ; 0.0052, p$-value $=0.0685)$ in Panel B. These results suggest that, compared to union membership ratio, the status of membership to an upper-level labor organization has a greater impact on corporate tax avoidance. The negotiation power of labor union by being alliance with upper-level labor organizations is significantly related to a greater pressure of management to secure corporate resources for union members through tax avoidance activities. Besides, the regression coefficients of control variables have similar directions and magnitudes to those in Table 2.

\subsection{H3: Union alliance and tax avoidance}

Table 4 shows the test results of whether the federation of Korean Trade of Union affects the level of corporate tax avoidance.

In both panels, the regression coefficients of UNION_MINJU are positive and statistically significant at $1 \%$ level $(0.0105, p$-value $<0.01$; $0.0104, p$-value $<0.01)$. On the other hand, the coefficients of UNION_HANGUK are not significant $(0.0026, p$-value $=0.42 ; 0.0025, p$-val$\mathrm{ue}=0.43)$. This means that companies, which joined aggressive labor organization (Minju), have greater pressure from their labor unions so that they have a greater level of tax avoidance activities. In contrast, the firm's affiliation with moderate labor organization (Hanguk) does not have any significant impact on the management. These results are consistent with the prediction for $H 3$. 
Table 3. The bargaining power of labor union and tax avoidance activities

\begin{tabular}{|c|c|c|c|c|}
\hline \multicolumn{5}{|c|}{ Panel A: Firm-level bargaining power of labor union } \\
\hline \multirow[t]{2}{*}{ Variable } & \multicolumn{2}{|c|}{$\begin{array}{c}\text { Panel A1: } \\
\text { Dependent variable }=\text { TA1 }\end{array}$} & \multicolumn{2}{|c|}{$\begin{array}{c}\text { Panel A2: } \\
\text { Dependent variable }=\text { TA2 }\end{array}$} \\
\hline & Coefficient & $p$-value & Coefficient & $p$-value \\
\hline Intercept & -0.0518 & 0.0177 & -0.0511 & 0.0186 \\
\hline UNION_REGI it & 0.0060 & 0.3373 & 0.0052 & 0.3951 \\
\hline $\mathrm{SIZE}_{\text {it }}$ & 0.0012 & 0.2938 & 0.0014 & 0.2024 \\
\hline LEVERAGE $_{i t}$ & 0.0310 & $<0.01$ & 0.0286 & $<0.01$ \\
\hline $\mathrm{ROA}_{\text {it }}$ & 0.2920 & $<0.01$ & 0.2190 & $<0.01$ \\
\hline INVEST $_{\text {it }}$ & -0.1493 & $<0.01$ & -0.1493 & $<0.01$ \\
\hline $\mathrm{DA}_{\mathrm{it}-1}$ & -0.1121 & $<0.01$ & 0.0196 & 0.5841 \\
\hline $\mathrm{OCF}_{\text {it }}$ & 0.0597 & 0.0813 & 0.1268 & $<0.01$ \\
\hline GRWA $_{\text {it }}$ & 0.1840 & $<0.01$ & 0.1800 & $<0.01$ \\
\hline $\mathrm{GRWL}_{\text {it }}$ & -0.0633 & $<0.01$ & -0.0626 & $<0.01$ \\
\hline FOR $_{\text {it }}$ & -0.0208 & 0.1097 & -0.0248 & 0.0496 \\
\hline $\mathrm{BIG}_{\text {it }}$ & 0.0061 & 0.3903 & 0.0073 & 0.2840 \\
\hline Industry fixed effect & \multicolumn{2}{|c|}{ YES } & \multicolumn{2}{|c|}{ YES } \\
\hline Year fixed effect & \multicolumn{2}{|c|}{ YES } & \multicolumn{2}{|c|}{ YES } \\
\hline Firm clustering & \multicolumn{2}{|c|}{ YES } & \multicolumn{2}{|c|}{ YES } \\
\hline Adj. $R^{2}$ & \multicolumn{2}{|c|}{0.293} & \multicolumn{2}{|c|}{0.2851} \\
\hline $\mathrm{N}$ & \multicolumn{2}{|c|}{2,351} & \multicolumn{2}{|c|}{2,351} \\
\hline
\end{tabular}

Panel B: Industry-level bargaining power of labor union

\begin{tabular}{|c|c|c|c|c|}
\hline \multirow[t]{2}{*}{ Variable } & \multicolumn{2}{|c|}{$\begin{array}{c}\text { Panel B1: } \\
\text { Dependent variable }=\text { TA1 }\end{array}$} & \multicolumn{2}{|c|}{$\begin{array}{c}\text { Panel B2: } \\
\text { Dependent variable }=\text { TA2 }\end{array}$} \\
\hline & Coefficient & $p$-value & Coefficient & $p$-value \\
\hline Intercept & -0.0399 & 0.0652 & -0.0426 & 0.0454 \\
\hline UNION_FED & 0.0055 & 0.0560 & 0.0052 & 0.0685 \\
\hline $\mathrm{SIZE}_{i t}$ & 0.0006 & 0.6135 & 0.0008 & 0.4618 \\
\hline LEVERAGE $_{\text {it }}$ & 0.0266 & $<0.01$ & 0.0239 & $<0.01$ \\
\hline $\mathrm{ROA}_{\text {it }}$ & 0.2883 & $<0.01$ & 0.2123 & $<0.01$ \\
\hline INVEST $_{\text {it }}$ & -0.1426 & $<0.01$ & -0.1440 & $<0.01$ \\
\hline $\mathrm{DA}_{\mathrm{it}-1}$ & -0.1139 & $<0.01$ & 0.0215 & 0.5406 \\
\hline $\mathrm{OCF}_{\mathrm{it}}$ & 0.0636 & 0.0638 & 0.1351 & $<0.01$ \\
\hline GRWA $_{\text {it }}$ & 0.1825 & $<0.01$ & 0.1781 & $<0.01$ \\
\hline $\mathrm{GRWL}_{\text {it }}$ & -0.0637 & $<0.01$ & -0.0624 & $<0.01$ \\
\hline $\mathrm{FOR}_{\text {it }}$ & -0.0215 & 0.1046 & -0.0247 & 0.0567 \\
\hline$B I G_{i t}$ & 0.0054 & 0.4530 & 0.0062 & 0.3680 \\
\hline Industry fixed effect & \multicolumn{2}{|c|}{ YES } & \multicolumn{2}{|c|}{ YES } \\
\hline Year fixed effect & \multicolumn{2}{|c|}{ YES } & \multicolumn{2}{|c|}{ YES } \\
\hline Firm clustering & \multicolumn{2}{|c|}{ YES } & \multicolumn{2}{|c|}{ YES } \\
\hline Adj. $R^{2}$ & \multicolumn{2}{|c|}{0.2889} & \multicolumn{2}{|c|}{0.28} \\
\hline $\mathrm{N}$ & \multicolumn{2}{|c|}{2,351} & \multicolumn{2}{|c|}{2,351} \\
\hline
\end{tabular}


Table 4. The membership of the Federation of Korean Trade of Union and tax avoidance activities; Minju vs. Hanguk

\begin{tabular}{|c|c|c|c|c|}
\hline \multirow[t]{2}{*}{ Variable } & \multicolumn{2}{|c|}{$\begin{array}{c}\text { Panel A: } \\
\text { Dependent variable } \\
=\text { TA1 }\end{array}$} & \multicolumn{2}{|c|}{$\begin{array}{l}\text { Panel B: } \\
\text { Dependent variable } \\
=T A 2\end{array}$} \\
\hline & Coefficient & $p$-value & Coefficient & $p$-value \\
\hline Intercept & -0.0443 & 0.0431 & -0.0441 & 0.0428 \\
\hline UNION_MINJU & 0.0105 & $<0.01$ & 0.0104 & $<0.01$ \\
\hline UNION_HANGUK & 0.0026 & 0.4204 & 0.0025 & 0.4380 \\
\hline SIZE $_{i t}$ & 0.0008 & 0.4758 & 0.0011 & 0.3492 \\
\hline LEVERAGE $_{i t}$ & 0.0293 & $<0.01$ & 0.0269 & $<0.01$ \\
\hline $\mathrm{ROA}_{\text {it }}$ & 0.2892 & $<0.01$ & 0.2165 & $<0.01$ \\
\hline INVEST $_{\text {it }}$ & -0.1502 & $<0.01$ & -0.1500 & $<0.01$ \\
\hline $\mathrm{DA}_{\mathrm{it}-1}$ & -0.1108 & $<0.01$ & 0.0208 & 0.5615 \\
\hline $\mathrm{OCF}_{\text {it }}$ & 0.0639 & 0.0622 & 0.1307 & $<0.01$ \\
\hline GRWA $_{\text {it }}$ & 0.1841 & $<0.01$ & 0.1800 & $<0.01$ \\
\hline $\mathrm{GRWL}_{\mathrm{it}}$ & -0.0633 & $<0.01$ & -0.0626 & $<0.01$ \\
\hline $\mathrm{FOR}_{\mathrm{it}}$ & -0.0211 & 0.1069 & -0.0251 & 0.0481 \\
\hline $\mathrm{BIG}_{\text {it }}$ & 0.0050 & 0.4795 & 0.0062 & 0.3620 \\
\hline $\begin{array}{l}\text { Industry fixed } \\
\text { effect }\end{array}$ & YES & & YES & \\
\hline Year fixed effect & YES & & YES & \\
\hline Firm clustering & YES & & YES & \\
\hline $\operatorname{Adj} . R^{2}$ & 0.295 & & 0.287 & \\
\hline N & 2,35 & & 2,35 & \\
\hline
\end{tabular}

\subsection{Additional tests: chaebols vs. non-chaebols}

The authors perform additional tests to address the impact of firms' affiliation with major Korean business groups (i.e., chaebols) on the relationship between labor union and tax avoidance. For this, they estimate the regression model used in the main tests using two sub-samples: chaebol firms versus non-chaebol firms.

As a result, the authors find that the main results do not hold for chaebol firms, suggesting that labor unions in chaebol-affiliated firms do not significantly affect corporate tax avoidance activity. On the contrary, the effect of labor unions on tax avoidance is still significant for non-chaebol firms. These results indicate that due to certain chaebol firms' ownership structure, the negotiation of labor unions does not pressure management to engage in tax avoidance activity to secure wages for union members.
Table 5. Sensitivity test: labor union and tax avoidance activities for chaebol vs. non-chaebol firms

\begin{tabular}{|c|c|c|c|c|}
\hline \multirow[t]{2}{*}{ Variable } & \multicolumn{2}{|c|}{ Chaebol firms } & \multicolumn{2}{|c|}{$\begin{array}{l}\text { Non-chaebol } \\
\text { firms }\end{array}$} \\
\hline & & $p$-value & & $p$-value \\
\hline \multicolumn{5}{|c|}{ A. Unionization } \\
\hline UNION $_{\text {it }}$ & -0.0032 & 0.5775 & 0.0068 & 0.0161 \\
\hline \multicolumn{5}{|c|}{ B. Firm-level bargaining power of labor union } \\
\hline UNION_REGI ${ }_{i t}$ & 0.0051 & 0.5861 & 0.0037 & 0.6501 \\
\hline \multicolumn{5}{|c|}{ C. Industry-level bargaining power of labor union } \\
\hline UNION_FEDit & -0.0009 & 0.8750 & 0.0067 & 0.0361 \\
\hline \multicolumn{5}{|c|}{$\begin{array}{l}\text { D. Membership of the Federation of Korean Trade } \\
\text { of Union }\end{array}$} \\
\hline UNION_MINJU & -0.0025 & 0.6888 & 0.0159 & $<0.01$ \\
\hline UNION_HANGUK ${ }_{\mathrm{it}}$ & 0.0001 & 0.9861 & 0.0029 & 0.4272 \\
\hline $\begin{array}{l}\text { Intercept \& Control } \\
\text { variables }\end{array}$ & \multicolumn{2}{|c|}{ Included } & \multicolumn{2}{|c|}{ Included } \\
\hline Industry fixed effect & \multicolumn{2}{|c|}{ YES } & \multicolumn{2}{|c|}{ YES } \\
\hline Year fixed effect & \multicolumn{2}{|c|}{ YES } & \multicolumn{2}{|c|}{ YES } \\
\hline Firm clustering & \multicolumn{2}{|c|}{ YES } & \multicolumn{2}{|c|}{ YES } \\
\hline $\mathrm{N}$ & \multicolumn{2}{|c|}{868} & \multicolumn{2}{|c|}{2,737} \\
\hline
\end{tabular}

\section{DISCUSSION}

The authors discuss the important contributions of the study in this section. First, this is the first study that verified the effects of labor unions, a firm's key stakeholder, on a firm's tax avoidance activity. Prior studies mainly paid attention to firm characteristics and corporate governance, namely shareholders and creditors, as the factors affecting the firms' tax avoidance. This study presented various implications on how labor unions affect corporate tax avoidance activity.

Second, this study improved the research setting to examine the relation between labor unions and tax avoidance activities. The authors avoided the self-selection bias by exploiting a Korean setting where the disclosure of labor costs is mandatory for all publicly traded firms. Since firm-level unionization data is available for comprehensive coverage of firms, it was possible to accurately es- 
timate the relation between labor unions and tax avoidance activities.

Moreover, this study contributed to the literature by examining the effects of labor unions' affiliations with an upper-level labor organization, which could measure the negotiation power of labor union, on tax avoidance. This is unique to the existing literature using Korean data. This study is important in that it has additionally verified the effects of the status of a labor union's membership to an upper level labor organization, which can serve as the alternative proxy of a labor union's negotiation power that can be checked through Korean data.

However, a measurement error problem still exists when measuring tax avoidance activity level and a labor union's effects. Follow-up studies addressing such a problem are expected to be carried out.

\section{CONCLUSION}

This study analyzed the effects of labor unions on a manager's tax avoidance activities. Specifically, unionization, union ratio, the status of joining an upper level labor organization, and the status of joining a belligerent upper level labor organization were measured while the effects of labor unions on a manager's tax avoidance activity were analyzed.

The analysis results of this study can be summarized as follows. As a result of an empirical analysis on the disclosed data of Korea's unique labor unions, namely mandatory disclosure of labor union-related data until 2008, the status of a labor union's existence did not affect a company's tax avoidance activity. However, when it comes to an analysis of the companies that have organized labor unions, the union ratio widely used as the alternative value of a labor union's effect in prior studies did not have a statistically significant effect on a company's tax avoidance activity. However, the status of a labor union's joining an upper level labor organization had an effect in increasing a company's tax avoidance activity on average. Companies whose labor unions joined a belligerent upper level labor organization especially showed statistically and significantly higher tax avoidance activities, compared to those that joined a moderate upper level labor organization. As a result of additional analysis, the labor union's effects on a company's tax avoidance activities were found to be consolidated in non-conglomerate groups compared to conglomerate groups.

\section{AUTHOR CONTRIBUTIONS}

Conceptualization: Ilhang Shin.

Formal analysis: Ilhang Shin.

Investigation: Ilhang Shin.

Methodology: Ilhang Shin.

Project administration: Sorah Park.

Writing - original draft: Sorah Park.

Writing - review \& editing: Sorah Park.

\section{REFERENCES}

1. Banning, K., \& Chiles, T. (2007).

Trade-offs in the Labor UnionCEO Compensation Relationship. Journal of Labor Research, 28(2), 347-357. https://doi.org/10.1007/ BF03380050

2. Bova, F. (2013). Labor Unions and Management's Incentive to Signal a Negative Outlook. Contemporary Accounting Research, 30(1), 14-41. https://doi.org/10.1111/j.19113846.2012.01160.x

3. Bronars, S. G., \& Deere, D. R. (1991). The Threat of Unionization, The Use of Debt, and The Preservation of Shareholder Wealth. The Quarterly Journal of Economics, 106(1), 231-254. https://doi. org/10.2307/2937914

4. Bronars, S. G., \& Deere, D. R. (1993). Union Organizing Activity, Firm Growth, and The Business Cycle. The American Economic 
Review, 83(1), 203-220. Retrieved from https://www.jstor.org/ stable/2117504

5. Chen, H. J., Kacperczyk, M., \& Ortiz-Molina, H. (2011). Labor Unions, Operating Flexibility, and The Cost of Equity. Journal of Financial and Quantitative Analysis, 46(1), 25-58. Retrieved from http://pages.stern.nyu. edu/ sternfin/mkacperc/public_html/unions.pdf

6. Choi, D. C., \& Suh, J. R. (2013). A Study on the Relationship between Corporate Governance Structures and Tax Avoidance. Review of Accounting and Policy Studies, 18(1), 1-27. (In Korean)

7. Clark, K. B. (1984). Unionization and Firm Performance: The Impact on Profits, Growth, and Productivity. American Economic Review, 74(5), 893-919. Retrieved from https://www.jstor.org/ stable/551

8. Connolly, R. A., Hirsch, B. T., \& Hirschey, M. (1986). Union Rent Seeking, Intangible Capital, and Market Value of the Firm. The Review of Economics and Statistics, 68(4), 567-577. Retrieved from https://www.jstor.org/stable/1924515

9. Croson, R. (2005). The Method of Experimental Economics. International Negotiation, 10(1), 131-148. Retrieved from https:// econlab.uaa.alaska.edu/iasc2013/ IASC2013/Readings_files/Croson2005.pdf

10. Cullinan, C. P., \& Knoblett, J. A. (1994). Unionization and Accounting Policy Choices: An Empirical Examination. Journal of Accounting and Public Policy, 13(1), 49-78. https://doi. org/10.1016/0278-4254(94)90012-4

11. DeAngelo, H., \& Masulis, R. W. (1980). Leverage and Dividend Irrelevancy under Corporate and Personal Taxation. The Journal of Finance, 35(2), 453-464. Retrieved from https://www.jstor.org/stable/2327405

12. Desai, M. A., \& Dharmapala, D. (2005). Corporate Tax Avoidance and Firm Value (NBER Working Paper No. 11241). Retrieved from https://www.nber.org/papers/ w11241
13. Desai, M. A., \& Dharmapala, D. (2006). Corporate Tax Avoidance and High-Powered Incentives. Journal of Financial Economics, 79(1), 145-179. https://doi. org/10.1016/j.jfineco.2005.02.002

14. Desai, M. A., Foley, C. F., \& Hines, J. R. (2004). Economic Effects of Regional Tax Havens (NBER Working Paper No. 10806). Retrieved from https://www.nber. org/papers/w10806

15. Dyreng, S., Hanlon, M., \& Maydew, E. (2008). Long-Run Corporate Tax Avoidance. The Accounting Review, 83(1), 61-82. Retrieved from https://www.jstor.org/stable/30243511

16. Fama, E. (1980). Agency Problems and the Theory of the Firm. Journal of Political Economy, 88(2), 288307. Retrieved from https://www. jstor.org/stable/1837292

17. Fama, E., \& Jensen, M. (1983) Separation of Ownership and Control. Journal of Law and Economic, 26(2), 301-325. https:// doi.org/10.1086/467037

18. Farber, D. B., Hsieh, H., Jung, B., \& Yi, H. (2010). Labor Unions and Accounting Conservatism (Working Paper). Retrieved from https:// www.semanticscholar.org/paper/ Labor-Unions-and-AccountingConservatism-Farber-Hsieh/ a556197796b5b3e9fc35ddb977f2b83a92083929

19. Graham, J. R., \& Tucker, A. L. (2006). Tax Shelters and Corporate Debt Policy. Journal of Financial Economics, 81(3), 563-594. https://doi.org/10.1016/j.jineco.2005.09.002

20. Griffith, R. (2001). Product Market Competition, Efficiency and Agency Cost: An Empirical Analysis (IFS Working Papers, No. 01/12). Institute for Fiscal Studies (IFS), London. http://dx.doi.org/10.1920/ wp.ifs.2001.0112

21. Grout, P. A. (1984). Investment and Wages in the Absence of Binding Contracts: A Nash Bargaining Approach. Econometrica, 52(2), 449-460. http://dx.doi. org/10.2307/1911498
22. Grullon, G., \& Michaely, R. (2007). Corporate Payout Policy and Product Market Competition. SSRN Electronic Journal. Retrieved from https://pdfs.semanticscholar. org/8b60/3ca892b5f266570545a307 1eb454fbaa07ee.pdf

23. Hilary, G. (2006). Organized Labor and Information Asymmetry in the Financial Markets. Review of Accounting Studies, 11(4), 525-548. https://doi.org/10.1007/s11142006-9015-y

24. Hirsch, B. T. (1992). Firm Investment Behavior and Collective Bargaining Strategy. Industrial Relations: A Journal of Economy and Society, 31(1), 95-121. https:// doi.org/10.1111/j.1468-232X.1992. tb00300.x

25. Hirsch, B. T., \& Link, A. N. (1987). Labor Union Effects on Innovative Activity. Journal of Labor Research, 8(4), 323-332. https://doi org/10.1007/BF02685217

26. Jeon, K. A. (2004). The Influence on Book-Tax Earnings Differences of Tax Costs and Nontax Costs. Korean Accounting Review, 29(1), 29-56. (In Korean)

27. Kim, J. H., \& Jeong, J. W. (2006). The Effect of Corporate Financial Characteristics on Tax Avoidance. Korean Journal of Taxation Research, 23(4), 97-123. (In Korean)

28. Kim, J. H., Choi, W. W., \& Koh, Y. S. (2007). A Study on Corporate Tax Avoidance. Korean Journal of Taxation Research, 24(4), 9-40. (In Korean)

29. Klasa, S., Maxwell, W., \& OrtizMolina, H. (2009). The Strategic Use of Corporate Cash Holdings in Collective Bargaining with Labor Unions. Journal of Financial Economics, 92(3), 421-442. https://doi.org/10.1016/j.jfineco.2008.07.003

30. Kleiner, M. M., \& Bouillon, M L. (1988). Providing Business Information to Production Workers: Correlates of Compensation and Profitability. ILR Review, 41(4), 605-617. Retrieved from https://ideas. repec.org/a/sae/ilrrev/v4ly1988i4p605-617.html 
31. Liberty, S. E., \& Zimmerman, J. L. (1986). Labor Union Contract Negotiations and Accounting Choices. The Accounting Review, 61(4), 692-712. Retrieved from https://www.jstor.org/stable/247364

32. Manzon, G. B., \& Plesko, G. A. (2001). The Relation Between Financial and Tax Reporting Measures of Income (MIT Sloan Working Paper No. 433201). https://doi.org/10.2139/ ssrn. 264112

33. Matsa, D. A. (2010). Capital Structure as a Strategic Variable: Evidence from Collective Bargaining. The Journal of Finance, 65(3), 1197-1232. https://doi.org/10.1111/j.15406261.2010.01565.x

34. Mautz, R. D., \& Richardson, F. M. (1992). Employer Financial Information and Wage Bargaining: Issues and Evidence. Labor Studies Journal, 17(3), 35-52.
35. Oh, W. R., \& Kim, Y. S. (2015). The Effects of Corporate Governance on the Tradeoff Relation between Aggressive Financial Reporting and Aggressive Tax Reporting. Review of Accounting and Policy Studies, 20(3), 1-24. (In Korean)

36. Park, J. K., Lee, K. W., \& Hong, Y. E. (2009). Managerial Ownership and Distinctive Properties of Tax Avoidance Strategy. Korean Journal of Taxation Research, 26(4), 125-147. (In Korean).

37. Petersen, M. A. (2009). Estimating Standard Errors in Finance Panel Data Sets: Comparing Approaches. The Review of Financial Studies, 22(1), 435-480. Retrieved from https://www.jstor. org/stable/40056916

38. Schallheim, J., \& Wells, K. (2004). Are firms Really Under-Levered? (Unpublished Working Paper). University of Utah, Salt Lake City, UT. Retrieved from https://pdfs. semanticscholar.org/01d7/6a645 3d4b7dbe6e99182ec43e2634e4f $9 \mathrm{dbc} . \mathrm{pdf}$

39. Scott, T. W. (1994). Incentives and Disincentives for Financial Disclosure: Voluntary Disclosure of Defined Benefit Pension Plan Information by Canadian Firms. The Accounting Review, 69(1), 26-43. Retrieved from https:// www.jstor.org/stable/248259

40. Wilson, R. J. (2009). An Examination of Corporate Tax Shelter Participants. The Accounting Review, 84(3), 969999. https://doi.org/10.2308/ accr.2009.84.3.969

41. Yoon, C., \& Lee, D. (2008). A Study on the Effect of Collectivism on Union Militancy among Union Leaders. Korean Human Resource Management Journal, 32(2), 23-53. (In Korean) 